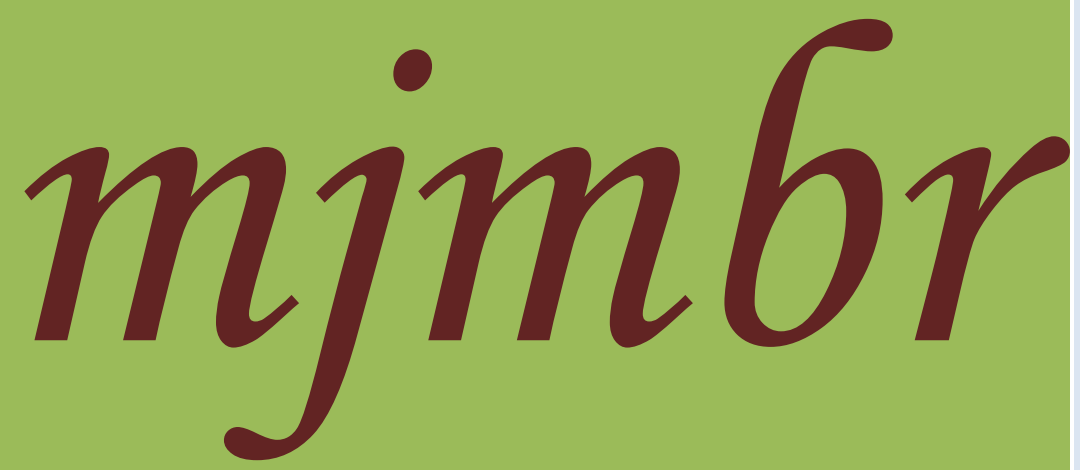

Malaysian Journal of Medical and Biological Research

www.jmbr-my.weebly.com

Vol 1, No. 1, 2014 


\title{
Emperical Study about Fears and Misconceptions of Aids and Hepatitis among Medical Students
}

\author{
Ammarah Ghafoor, \& Adeel Ahmad Khan
}

Firdaus Colony Gulgasht, Multan, Pakistan

\begin{abstract}
Background: A number of evaluations regarding awareness among people about modes of transmission, sources of transmission and vaccination against HBV, HCV and HIV have been carried out but very few of them have specifically focused medical students. This study reflects the degree of awareness of $3^{\text {rd }}$ year MBBS students on these issues and their vaccination status. It also depicts whether medical students are afraid of examining patients afflicted with these diseases or not.

Objectives: To determine the knowledge of medical students about various aspects of HBV, HCV and HIV.

Methodology: This is an observational cross-sectional study with prospective data, done through a questionnaire survey on $1303^{\text {rd }}$ year M.B.B.S students.

Results: Knowledge of students about modes of transmission of HBV, HCV and HIV: $28.4 \%$ complete/ $70.7 \%$ incomplete/ $0.007 \%$ no knowledge

1. Fear among students for examination of patients with HBV, HIV and HCV: $40 \%$ afraid/ $60 \%$ not afraid

2. Knowledge of students about availability of vaccination against HBV, HCV and HIV: HBV : $80.7 \%$ HCV: $42.3 \%$ HIV: $16.9 \%$

3. Vaccination status of students against HBV: $81.5 \%$ vaccinated/19.5\% not vaccinated

Conclusion: The percentage of students having complete knowledge about
\end{abstract} these diseases is lower than that is expected.

Key Words: Modes of transmission, source of transmission, vaccination

crossref DOI: $10.15590 / \mathrm{mjmbr} / 2014 / \mathrm{v} 1 \mathrm{i1} / 53717$

License: CC-BY-NC

\section{INTRODUCTION}

Reports of successful antiviral therapy for chronic hepatitis B virus (HBV) infection appeared three decades ago, and during the past decade, progress has accelerated dramatically. Along with progress, however, has come complexity. So much more is known now than at the dawn of the antiviral era about the protean clinical expressions of HBV infection that determining whom, when, and how to treat has become progressively more challenging. 
Hepatitis B virus (HBV) infection and its sequel are major global health problems [1]. The natural history of hepatitis $B$ is complex and is influenced by many factors, including age at infection, viral factors(HBV genotype, viral mutations, level of HBV replication), host factors(gender, age and immune status), and exogenous factors such as concurrent infection with other hepatotropic viruses and alcohol. The clinical spectrum of HBV infection ranges from subclinical to acute symptomatic hepatitis or, rarely, fulminant hepatitis during acute phase and from the inactive hepatitis B surface antigen (HBsAg) carrier state to chronic hepatitis, cirrhosis, and its complications during the chronic phase ${ }^{[3,4]}$. Approximately 15- $40 \%$ of people who develop chronic HBV infection are expected to progress to cirrhosis and endstage liver disease ${ }^{[1]}$. Difficulties in defining the natural history of chronic hepatitis B include the indolent course of the disease, the lack of symptoms during the early stages, and the heterogeneity of the disease. Understanding the natural history and prognosis of hepatitis B is the basis for disease management and for designing better therapeutic strategies. ${ }^{[2]}$

$\mathrm{HBV}$, a DNA virus transmitted parenterally, sexually, and perinatally, affects $\mathbf{1 . 2 5}$ million persons in the United States and $\mathbf{3 5 0}$ to $\mathbf{4 0 0}$ million persons worldwide. HBV infection accounts annually for $\mathbf{4 0 0 0}$ to $\mathbf{5 5 0 0}$ deaths in the United States and $\mathbf{1}$ million deaths worldwide from cirrhosis, liver failure, and hepatocellular carcinoma.[2,5-8] Hepatitis C virus (HCV) infects an estimated 170 million persons worldwide and thus represents a viral pandemic, one that is five times as widespread as infection with the human immunodeficiency virus type 1 (HIV-1). The institution of blood-screening measures in developed countries has decreased the risk of transfusion-associated hepatitis to a negligible level, but new cases continue to occur mainly as a result of injection-drug use and, to a lesser degree, through other means of percutaneous or mucous-membrane exposure. Progression to chronic disease occurs in the majority of $\mathrm{HCV}$-infected persons, and infection with the virus has become the main indication for liver transplantation. HCV infection also increases the number of complications in persons who are coinfected with HIV-1. Although research advances have been impeded by the inability to grow HCV easily in culture, there have been new insights into pathogenesis of the infection and improvements in treatment options. ${ }^{[9]}$

Human immunodeficiency virus / acquired immunodeficiency syndrome (HIV/AIDS) is a disease of the human immune system caused by infection with human immunodeficiency virus (HIV). ${ }^{[10]} \mathrm{HIV}$ is transmitted primarily via unprotected sexual intercourse (including anal and even oral sex), contaminated blood transfusions, hypodermic needles, and from mother to child during pregnancy, delivery, or breastfeeding. ${ }^{[11]}$ Some bodily fluids, such as saliva and tears, do not transmit HIV. ${ }^{[12]}$ Genetic research indicates that HIV originated in west-central Africa during the early twentieth century.[13] AIDS was first recognized by the Centers for Disease Control and Prevention (CDC) in 1981 and its cause-HIV infection - was identified in the early part of the decade.[14] Since its discovery, AIDS has caused nearly $\mathbf{3 0}$ million deaths (as of 2009). ${ }^{[15]}$ As of 2010, approximately 34 million people have contracted HIV globally. ${ }^{[16]}$ AIDS is considered a pandemic - a disease outbreak which is present over a large area and is actively spreading. ${ }^{[17]}$

\section{LITERATURE REVIEW}

${ }^{[18]}$ Hepatitis B is a potentially life-threatening liver infection caused by the hepatitis B virus. It is a major global health problem and the most serious type of viral hepatitis. It can cause chronic liver disease and puts people at high risk of death from cirrhosis of the liver and liver cancer. Worldwide, an estimated two billion people have been infected with the hepatitis B virus and more than 240 million have chronic (long-term) liver infections. 
About 600000 people die every year due to the acute or chronic consequences of hepatitis B. A vaccine against hepatitis B has been available since 1982. Hepatitis B vaccine is $95 \%$ effective in preventing infection and its chronic consequences, and is the first vaccine against a major human cancer.

Hepatitis B virus can cause an acute illness with symptoms that last several weeks, including yellowing of the skin and eyes (jaundice), dark urine, extreme fatigue, nausea, vomiting and abdominal pain. Hepatitis B is endemic in China and other parts of Asia. Most people in this region become infected with the hepatitis B virus during childhood and $8-10 \%$ of the adult population is chronically infected. Liver cancer caused by hepatitis $\mathrm{B}$ is among the first three causes of death from cancer in men, and a major cause of cancer in women in this region.

High rates of chronic infections are also found in the Amazon and the southern parts of eastern and central Europe. In the Middle East and Indian subcontinent, an estimated 2$5 \%$ of the general population is chronically infected. Less than $1 \%$ of the population in Western Europe and North America is chronically infected.

Hepatitis B virus is transmitted between people by direct blood-to-blood contact or semen and vaginal fluid of an infected person. Modes of transmission are the same as those for the human immunodeficiency virus (HIV), but the hepatitis B virus is 50 to 100 times more infectious. Unlike HIV, the hepatitis B virus can survive outside the body for at least seven days. During this time, the virus can still cause infection if it enters the body of a person who is not protected by the vaccine.

In developing countries, common modes of transmission are:

- Perinatal (from mother to baby at birth)

- Early childhood infections (inapparent infection through close interpersonal contact with infected household contacts)

- Unsafe injection practices

- Unsafe blood transfusions

- Unprotected sexual contact.

The hepatitis B virus is not spread by contaminated food or water, and cannot be spread casually in the workplace. ${ }^{[18]}$

${ }^{[19]}$ Hepatitis $\mathbf{C}$ is a contagious liver disease that results from infection with the hepatitis $C$ virus. It can range in severity from a mild illness lasting a few weeks to a serious, lifelong illness. The hepatitis $C$ virus is usually spread when blood from an infected person enters the body of a susceptible person. It is among the most common viruses that infect the liver. Every year, 3-4 million people are infected with the hepatitis C virus. About 150 million people are chronically infected and at risk of developing liver cirrhosis and/or liver cancer. More than 350000 people die from hepatitis C-related liver diseases every year.

Hepatitis $C$ is found worldwide. Countries with high rates of chronic infection are Egypt $(15 \%)$, Pakistan (4.8\%) and China (3.2\%). The main mode of transmission in these countries is attributed to unsafe injections using contaminated equipment.

The hepatitis $C$ virus is most commonly transmitted through exposure to infectious blood. This can occur through:

- Receipt of contaminated blood transfusions, blood products and organ transplants

- Injections given with contaminated syringes and needle-stick injuries in health-care settings

- Injection drug use

- Being born to a hepatitis C-infected mother. 
- Hepatitis C may be transmitted through sex with an infected person or sharing of personal items contaminated with infectious blood, but these are less common.

Hepatitis $C$ is not spread through breast milk, food or water or by casual contact such as hugging, kissing and sharing food or drinks with an infected person.[19]

[20]The Human Immunodeficiency Virus (HIV) targets the immune system and weakens people's surveillance and defense systems against infections and some types of cancer. As the virus destroys and impairs the function of immune cells, infected individuals gradually become immunodeficient. Immune function is typically measured by CD4 cell count. Immunodeficiency results in increased susceptibility to a wide range of infections and diseases that people with healthy immune systems can fight off. The most advanced stage of HIV infection is Acquired Immunodeficiency Syndrome (AIDS), which can take from 2 to 15 years to develop depending on the individual. AIDS is defined by the development of certain cancers, infections, or other severe clinical manifestations.

HIV can be transmitted via the exchange of a variety of body fluids from infected individuals, such as blood, breast milk, semen and vaginal secretions. Individuals cannot become infected through ordinary day-to-day contact such as kissing, hugging, shaking hands, or sharing personal objects, food or water. ${ }^{[20]}$

\section{Material AND Methodology}

Study design: Cross sectional descriptive study

Study Population: M.B.B.S. students of NMC $3^{\text {rd }}$ year

Study Area: Nishtar Medical College Multan

Sampling Technique: Non-probability convenient sample

Study population: $3^{\text {rd } y r}$. M.B.B.S. students of Nishtar Medical College Multan

Inclusion criteria: $3^{\text {rd }}$ yr. M.B.B.S. students of Nishtar Medical College Multan

Exclusion criteria: Anyone who does not fulfill these criteria.

Collection procedure: Primary data has been used in this study. The data was collected through a questionnaire.

Sample size: 130 students

Data Analyse: MS Office

\section{OBJectives}

- To determine the frequency of knowledge about the mode of transmission of HBV, $\mathrm{HCV}$ and HIV.

- To find out fear and misconceptions about the source of transmission among students.

\section{FINDINGS AND RESULTS}

\section{TABLE 1}

Frequency distribution table showing knowledge of students about modes of transmission of HBV, HCV and HIV.

TOTAL $=130$

\begin{tabular}{|l|c|c|c|c|c|c|}
\hline & \multicolumn{2}{|c|}{ COMPLETE } & \multicolumn{2}{c|}{ INCOMPLETE } & \multicolumn{2}{c|}{ NO KNOWLEDGE } \\
\hline & $\begin{array}{c}\text { Number of } \\
\text { students }\end{array}$ & $\%$ & $\begin{array}{c}\text { Number of } \\
\text { students. }\end{array}$ & $\begin{array}{c}\text { Number of } \\
\text { students }\end{array}$ & $\%$ \\
\hline KNOWLEDGE & 37 & 28.4 & 92 & 70.7 & 1 & 0.007 \\
\hline
\end{tabular}




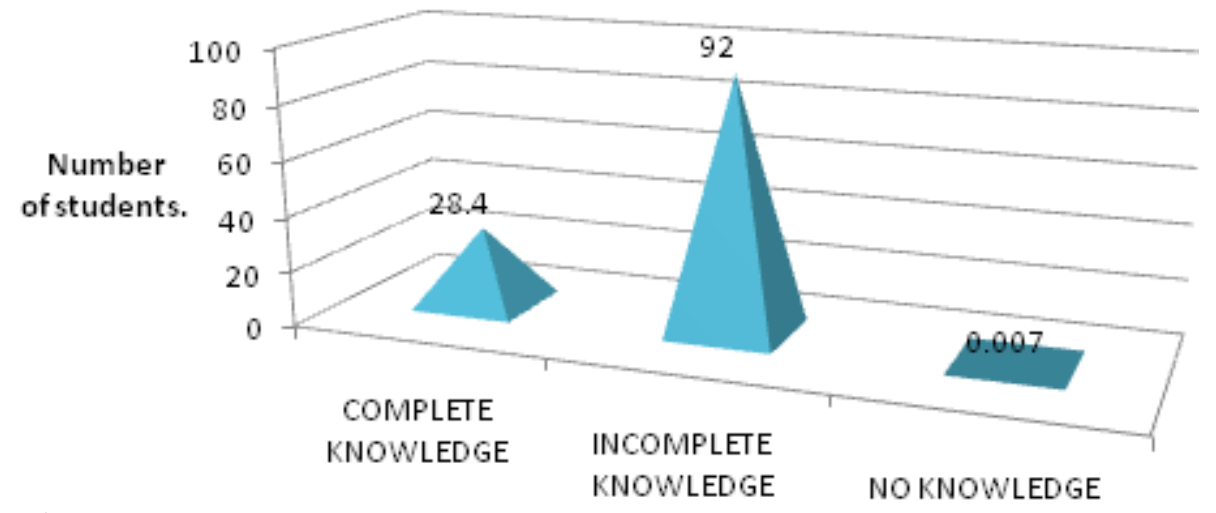

TABLE 2

KNOWLEDGE NOKNOWLEDGE

Frequency distribution table showing student's perception about sources of transmission of HBV, HCV and HIV (shows the number of students out of total of 130 who believed that the disease was transmissible by the mentioned source)

\begin{tabular}{|c|c|c|c|c|c|c|}
\hline SOURCES OF TRANSMISSION & \multicolumn{2}{|l|}{ HBV } & \multicolumn{2}{|l|}{ HCV } & \multicolumn{2}{|c|}{ HIV } \\
\hline & $\begin{array}{c}\text { Number of } \\
\text { students }\end{array}$ & $\%$ & $\begin{array}{l}\text { Number of } \\
\text { students }\end{array}$ & $\%$ & $\begin{array}{c}\text { Number of } \\
\text { students }\end{array}$ & $\%$ \\
\hline SWEAT & 28 & & 21 & & 27 & \\
\hline SALIVA & 92 & & 87 & & 83 & \\
\hline $\begin{array}{l}\text { INTACT SKIN TO SKIN CONTACT } \\
\text { DURING EXAMINATION }\end{array}$ & 13 & & 12 & & 16 & \\
\hline BED OF THE PATIENT & 27 & & 28 & & 29 & \\
\hline PATIENT'S CLOTHES & 29 & & 29 & & 27 & \\
\hline VOMITUS WITHOUT BLOOD & 58 & 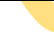 & 49 & & 52 & \\
\hline BLOOD & 120 & & 120 & & 126 & \\
\hline NEEDLE STICK INJURY & 116 & & 117 & & 111 & \\
\hline URINE & 43 & & 40 & & 38 & \\
\hline WOUND DRESSING & 74 & & 69 & & 70 & \\
\hline WOUND & 99 & & 99 & & 99 & \\
\hline DRAIN TUBES FLUID & 82 & & 77 & & 81 & \\
\hline SHARING EATING UTENSILS & 49 & & 49 & & 47 & \\
\hline HANDSHAKE & 11 & & 13 & & 11 & \\
\hline COUGH & 64 & & 69 & & 60 & \\
\hline VAGINAL SECRETIONS & 111 & & 108 & & 117 & \\
\hline SEMEN & 115 & & 120 & & 114 & \\
\hline SHARING NAIL CUTTER, COMBetc & 103 & & 102 & & 106 & \\
\hline
\end{tabular}




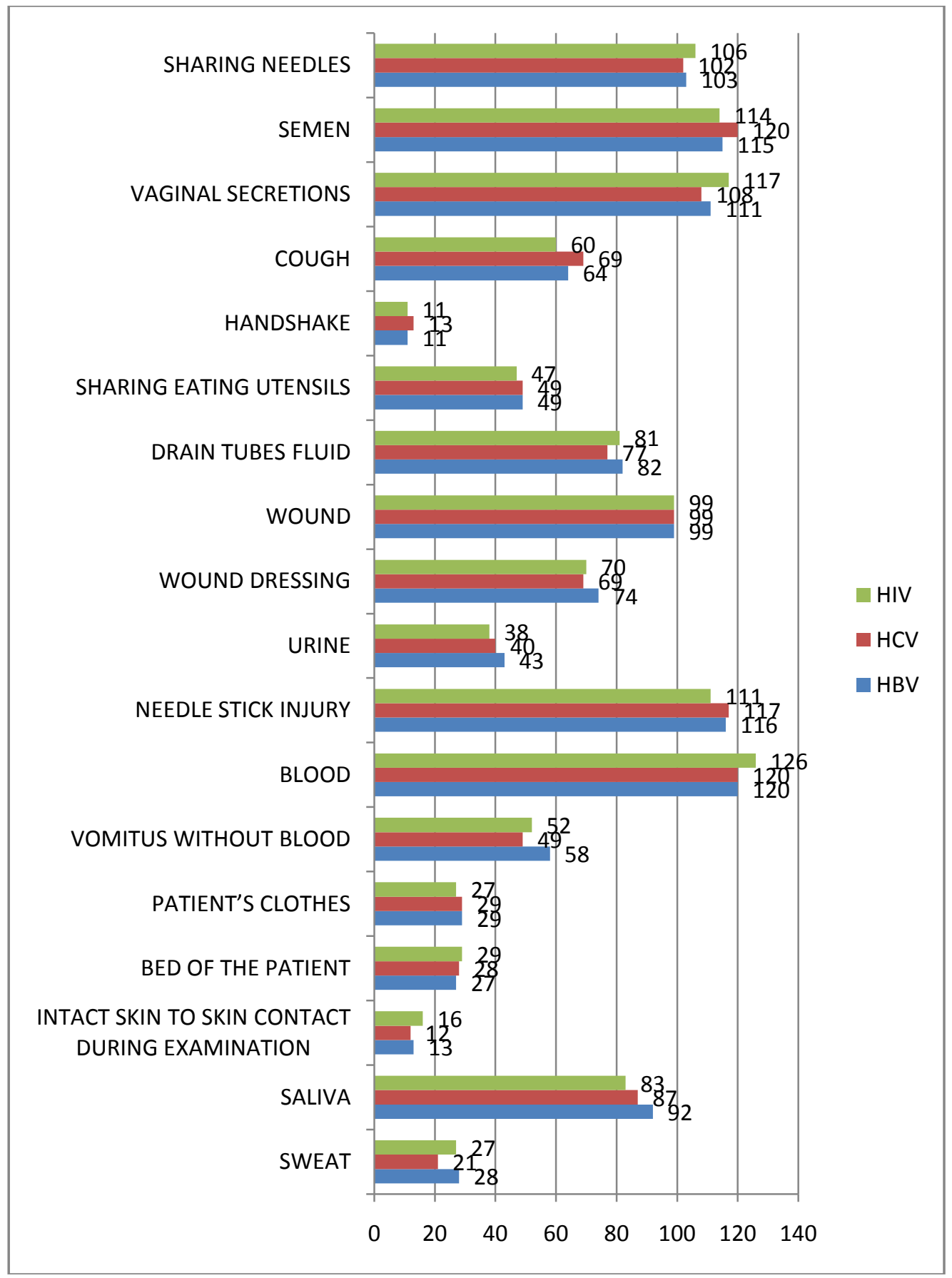




\section{TABLE 3}

Frequency distribution table showing fear among students for examination of patients with HBV, HIV and HCV.

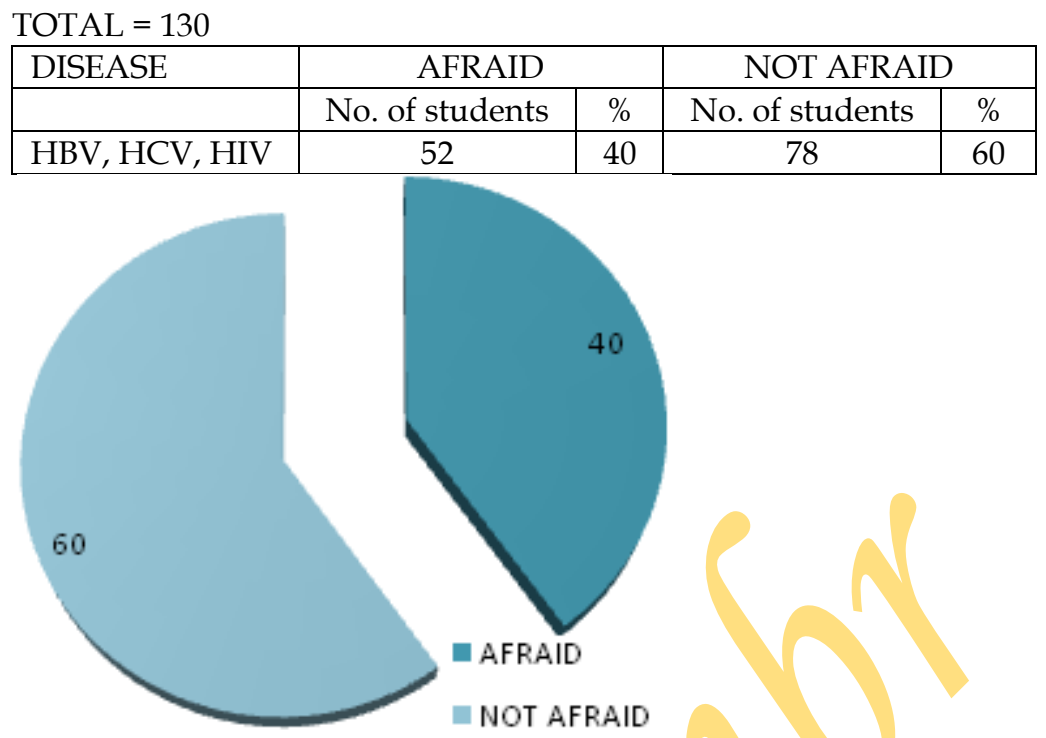

TABLE 4

Frequency distribution table showing knowledge of students about availability of vaccination against $\mathrm{HBV}, \mathrm{HCV}$ and $\mathrm{HIV}$.

TOTAL $=130$

\begin{tabular}{|l|c|c|c|c|}
\hline \multicolumn{1}{|c|}{ DISEASE } & \multicolumn{2}{c|}{ VACCINE AVAILABLE } & \multicolumn{2}{c|}{ VACCINE NOT AVAILABLE } \\
\hline HBV & Number of students & $\%$ & Number of students & $\%$ \\
\hline HCV & 105 & 80.7 & 25 & 19.3 \\
\hline HIV & 55 & 42.3 & 75 & 57.7 \\
\hline
\end{tabular}

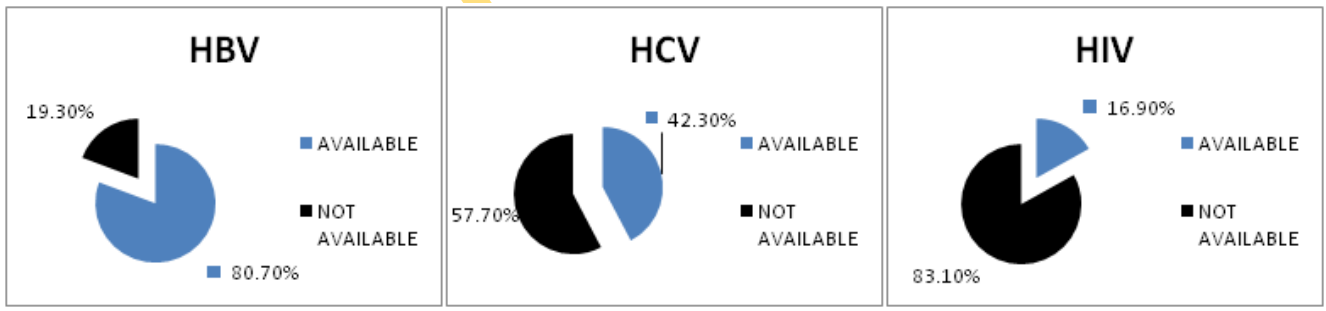

\section{TABLE 5}

Frequency distribution of vaccination status of students against HBV

Total $=130$

\begin{tabular}{|l|c|c|c|c|}
\hline DISEASE & \multicolumn{2}{|c|}{ VACCINATED } & \multicolumn{2}{c|}{ NOT VACCINATED } \\
\hline & Number of students & $\%$ & Number of students & $\%$ \\
\hline HBV & 106 & 81.5 & 24 & 19.5 \\
\hline
\end{tabular}




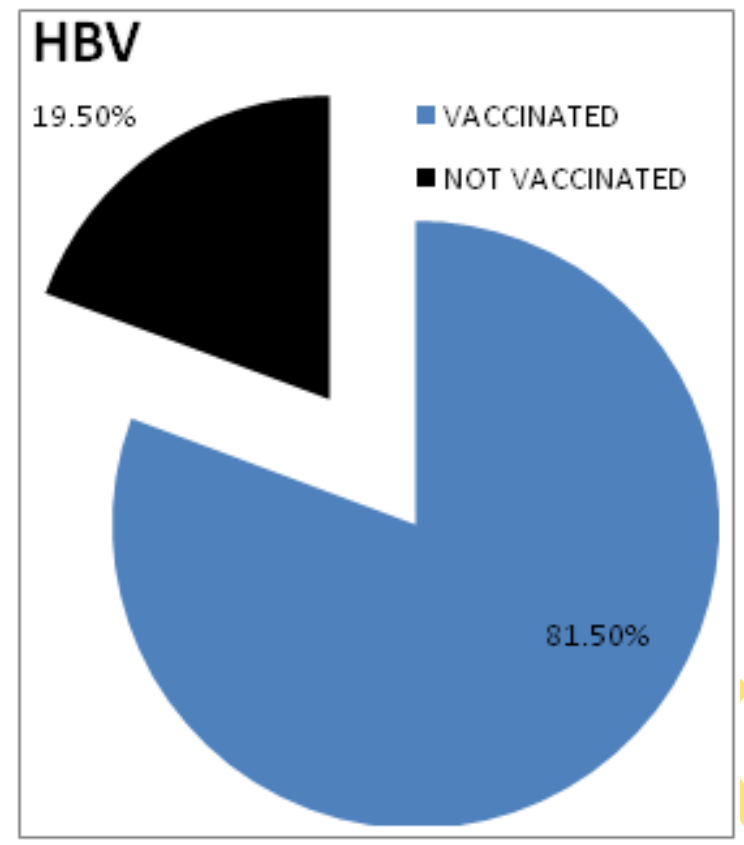

\section{Discussion}

Medical professionals play a very important in disease prevention and treatment. In view of this, it is very important that they should have a sound knowledge about sources, modes of transmission, hereditary patterns, signs and symptoms and preventive methods of diseases. This is important not only in providing better health facilities to the patients but also protects them from acquiring diseases in clinical settings as many diseases can be contracted through various accidents that may occur during examination of patients for example needle stick injuries, body fluids of patients with certain diseases and so on. Medical students are much more susceptible to such incidents as they are untrained and are usually unaware of the preventive measures that should be taken in this regard.

Many studies have been carried out all over the world to find out the extent of medical students' awareness about various aspects of HBV, HCV and HIV. According to a study carried out in Agha Khan Medical University, 90\% of medical students were aware of the fact that each of HBV, HCV and HIV can be transmitted via needle stick injuries ${ }^{21}$.The same study also indicated that more than $90 \%$ of the medical students who had participated in that survey had received all the three doses of hepatitis $\mathrm{B}$ vaccination ${ }^{22} \mathrm{~A}$ study conducted by Tehran University of Medical Sciences showed that $87.5 \%$ of the interns who had participated in survey had completed the HBV vaccination schedule.It also showed that only a minority of medical students observed basic safety measures during their training sessions in wards ${ }^{23}$

According to our study in Nishtar Medical College Multan, only 28.4\% students of $3^{\text {rd }}$ year MBBS had complete knowledge about the modes of transmission of HBV, HCV and HIV. $80.7 \%$ students were aware of the availability of vaccination against $\mathrm{HBV}$ and $81.5 \%$ students who participated in this survey had received all the three doses of hepatitis $B$ vaccination. 


\section{CONCLUSION}

From our study, the following conclusions can be drawn:

- The knowledge of most of our medical students about the modes of transmission of HBV, $\mathrm{HCV}$ and HIV is incomplete which is alarming because as future health professionals, they must know modes of transmission of such fatal diseases so that they may protect others and themselves from acquiring the disease from the infected patients.

- Most of the students knew the sources of transmission of these diseases but they also had wrong concepts about some sources that are not involved in the transmission of $\mathrm{HBV}, \mathrm{HCV}$ and HIV like intact skin to skin contact etc.

- It has been found that $40 \%$ of the students who participated in this survey were afraid of examining the patients infected with these diseases and they feared they may contract the disease while examining the patients

- Majority of the students had good knowledge about the availability of vaccination and $81.5 \%$ of the students were found to be vaccinated against HBV.

\section{RECOMMENDATIONS}

- Medical students should have complete knowledge about routes of transmission of $\mathrm{HBV}, \mathrm{HCV}$ and HIV.

- All medical students should be vaccinated against HBV because they can acquire these diseases from patients.

- All medical students should follow preventive measures while examining the patients because some viral diseases can be transmitted by needle stick injuries and other accidents that may take place in clinical settings.

- Special seminars providing information about these diseases should be conducted for medical students. Moreover, students should be encouraged to become part of the programs that are directed towards imparting education to the community about these fatal diseases.

\section{REFERENCES}

^ ab Sharp, PM; Hahn, BH (2011 Sep). "Origins of HIV and the AIDS Pandemic". Cold Spring Harbor perspectives in medicine 1 (1): a006841.doi:10.1101/cshperspect.a006841. PMC3234451.PMID22229120. [13]

$\wedge a b$ "Global Report Fact Sheet". UNAIDS. 2010. [15]

$\wedge$ abcdef UNAIDS 2011 pg. 1-10 [16]

$\wedge$ abcdefghij Markowitz, edited by William N. Rom ; associate editor, Steven B. (2007). Environmental and occupational medicine (4th ed.). Philadelphia: Wolters Kluwer/Lippincott Williams \& Wilkins. p. 745. ISBN978-0-7817-6299-1. [11]

$\wedge$ abKallings LO (2008). "The first postmodern pandemic: 25 years of HIV/AIDS". J Intern Med 263 (3): 218-43.doi:10.1111/j.1365-2796.2007.01910.x.PMID18205765.(subscription required). [17]

$\wedge$ Gallo RC (2006). "A reflection on HIV/AIDS research after 25 years". Retrovirology 3: 72. doi:10.1186/1742-4690-3-72. PMC1629027. PMID17054781. [14]

$\wedge$ "HIV and Its Transmission". Centers for Disease Control and Prevention. 2003. Archived from the original on February 4, 2005. Retrieved May 23, 2006. [12]

$\wedge$ Sepkowitz KA (June 2001). "AIDS-the first 20 years". N. Engl. J. Med.344 (23): 176472.doi:10.1056/NEJM200106073442306. PMID11396444. [10]

BatoulShariati et al Accidental Exposure to Blood in Interns of Tehran University of Medical Sciences, J Occup Health;2007;49;317-321. [23] 
Ganem D, Prince AM. Hepatitis B virus infection -- natural history and clinical consequences. N Engl J Med 2004;350:1118-1129[Erratum, N Engl J Med 2004;351:351.] [6]

Georg M. Lauer, M.D., and Bruce D. Walker, M.D. N Engl J Med 2001; 345:41-52July 5, 2001. [9]

Hoofnagle JH, Doo E, Liang TJ, Fleischer R, Lok AS. Management of hepatitis B: summary of a clinical research workshop. Hepatology 2007;45:1056-1075. [8]

Lee WM: Hepatitis B virus infection. N Engl J Med 1997, 337:1733-1745. [2]

Lok AS, Heathcote EJ, Hoofnagle JH. Management of hepatitis B: 2000 -- summary of a workshop. Gastroenterology 2001;120:1828-1853 CrossRef | Web of Science | Medline [5]

Lok AS, Heathcote EJ, Hoofnagle JH: Management of hepatitis B: 2000 - summary of a workshop. Gastroenterology 2001, 120:1828-1853. PubMed Abstract | Publisher Full Text. [3]

Lok AS, McMahon BJ. Chronic hepatitis B. Hepatology 2007;45:507-539[Erratum, Hepatology 2007;45:1347.] [7]

Lok ASF, McMahon BJ: Chronic hepatitis B. Hepatology 2001, 34:1225-1241. [4]

Maddrey WC: Hepatitis B: an important public health issue. J Med Virol 2000, 61:362-366. [1]

TaimorSaleem et al Knowledge, attitude and practices of medical students regarding NSIs JMAP Vol 60 NO 2 February 2010. [21]

TaimorSaleem et al Knowledge, attitude and practices of medical students regarding NSIs JMAP Vol 60 NO 2 February 2010. [22]

World Health Organization AIDS World Health Organization fact sheet no. 360 on November 2012. Available at http://www.who.int/mediacentre/factsheets/fs360/en/index.html [20]

World Health Organization Hepatitis B World Health Organization fact sheet no. 204 on July 2012. Available at http://www.who.int/mediacentre/factsheets/fs204/en/index.html (July 2012). [18]

World Health Organization Hepatitis C World Health Organization fact sheet no. 164 on July 2012. Available at http:/ / www.who.int/mediacentre/factsheets/fs164/en/index.html (July 2012). [19]

\section{Why Open Access ???}

"In the traditional publishing model, readers have limited access to scientific papers; authors do not have copyright for their own papers, and cannot post their papers on their own websites, which presents a significant barrier to the sharing of knowledge, as well as being unfair to authors. Open access can overcome the drawbacks of the traditional publishing model and help scholars build on the findings of their colleagues without restriction"

\section{Submit your next manuscript at- WWw.abcjournals.net}

ABC Journals is a unique forum to offer open access to all of its articles.

Now ABC Journals's portfolio is over ten journals, which publish both online and in print. 


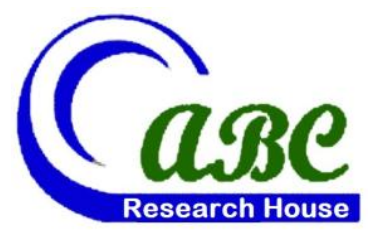

- Pantidalam, Kuala Lampur, Malaysia

- Rd 4, Shyamoli, Dhaka-1207, Bangladesh

- 3900 Woodhue Place, Alexandria, VA 22309, USA

www.abcreorg.weebly.com / www.abcjournals.net

Asian Business Consortium (ABC) is a multi-disciplinary research, training, publishing, digital library supporting and service house. Though founded in 2010 as the Business and Computing organization of Asia, it was reconstituted as the ABC in 2011. It has been working for creating and nurturing talents in USA, Malaysia and Bangladesh since its inception. As ABC is going global, it intends to open chapters in Australia, Germany, Japan, Pakistan, and other Asian countries in near future. The objectives of consortium are solely centered round the welfare and humane attitude of the founders who enthusiastically took up this noble cause and materialized it with a view to promote research and educational activities for the encouragement of scholars to develop their knowledge, to publish their analysis oriented scientific researches in international Journals, books, the task of organizing workshops, seminars, conferences, training, personality development programs and allied services.

In addition to research activities, ABC provides a good number of scholarships to the poor and meritorious students at various levels of education throughout the world. It plays an important role in the field of research by funding research projects and publishing the research papers. This consortium will unquestionably become the mouth-piece of the dark horses and unacknowledged scholar whose endowed and commendable contributions shall be provided an outlet keeping in mind the greater good of the larger society of the world.

$\mathrm{ABC}$ runs the following international referred journals for creating a platform to share the thoughts of professionals, scholars and academicians throughout the world.

\section{ABC Publications (ABC Journals)}

- Asian Accounting and Auditing Advancement (4A Journal)

- Asian Business Review (ABR)

- Asian Journal of Applied Sciences and Engineering (AJASE)

- Global Disclosure of Economics and Business (GDEB)

- $\quad$ ABC Journal of Advanced Research (ABC-JAR)

- International Journal of Reciprocal Symmetry and Theoretical Physics (IJRSTP)

- American Journal of Trade and Policy (AJTP)

- Asian Journal of Humanity, Art and Literature (AJHAL)

- Malaysian Journal of Medical and Biological Research (MJMBR)

- Asia Pacific Journal of Energy and Environment (APJEE)

- $\quad$ Engineering International (EI)

- $\quad$ ABC Research Alert (Online)

Each journal home page provides specific information for potential authors and subscribers. Open access policy, the quick review process, rich editorial boards and quality publications have already made $A B C$ Journals unique. ABC Journals are published under the direct supervisions of renowned academicians of the world.

Collaboration in Conference: ABC considers high-quality conference papers for publication. Please contact us for detailed information.

Collaboration in Publishing: If you like to start writing a book, propose a new journal or advertise in $\mathrm{ABC}$ journals, please feel free to contact us. 